\title{
The Regression Analysis of Individual Financial Performance: Evidence from Croatia
}

\author{
Vlasta Bahovec, Dajana Barbić, Irena Palić
}

Faculty of Economics and Business, University of Zagreb, Croatia

\section{Abstract}

Background: A large body of empirical literature indicates that gender and financial literacy are significant determinants of individual financial performance. Objectives: The purpose of this paper is to recognize the impact of the variable financial literacy and the variable gender on the variation of the financial performance using the regression analysis. Methods/Approach: The survey was conducted using the systematically chosen random sample of Croatian financial consumers. The cross section linear regression model is estimated in order to assess how gender as a dummy variable and financial literacy as an ordinal categorical variable impact financial performance. Results: The results indicate that the average value of financial performance for men is higher than the average value of financial performance for women at the same financial literacy level. Furthermore, a higher level of financially literacy is related to a higher level of financial performance. Conclusions: Both gender and financial literacy have a statistically significant impact on individual financial performance. Increasing financial literacy and understanding gender differences in terms of financial literacy and financial well-being should be of interest to financial educators in their struggles to improve financial situation of citizens and for educators to create financial education programs intended for men and women.

Keywords: financial literacy; financial performance; gender; regression analysis JEL classification: C30, C83, J16, 122

Paper type: Research article

Received: Apr 26, 2017

Accepted: Jul 16, 2017

Citation: Bahovec, V., Barbić, D., Palić, I. (2017), "The Regression Analysis of Individual Financial Performance: Evidence from Croatia", Business Systems Research, Vol. 8, No. 2, pp. 1-13.

DOI: 10.1515/bsrj-2017-0012

Acknowledgments: This work has been supported by the Croatian Science Foundation under the project STRENGTHS no. IP-2013-9402.

\section{Introduction}

The research of individual financial behavior has been very important subject in economic literature in the past decade. Moreover, it gained in importance after the latest financial crisis, which emphasized the potential risks of individuals' poor 
financial decisions. Findings of the relevant literature point to the fact that financial performance of individuals is strongly determined by different variables where some of them were given to the individuals by their birth, such as demographic variables, and other were acquired through their life, such as social and psychological variables (Hilgert et al., 2003; Lusardi and Mitchell, 2007; Cvrlje, 2014).

There is extensive evidence both in a Croatian and international literature that financial education of individuals is unsatisfactory since individuals are unfamiliar with elementary financial definitions, which affects their financial well-being but also the prosperity of the overall society (Bahovec et al., 2015). People who engage more in financial education should possess higher level of financial literacy and therefore demonstrate better financial behaviour and be more financially successful as opposed to those with lower level of financial literacy (Hilgert et al., 2003; Lusardi, 2008; Collins, 2010; Cvrlje et al., 2015; Barbić, 2017, etc.).

Unlike financial education which primarily depends on individual life choices and his will to acquire new knowledge and skills, there are other variables that also might determine individual financial performance but he has no power over affecting those variables. One such variable is gender. According to the empirical results of some studies, when it comes to financial literacy and financial performance, women are the especially vulnerable group. Large body of empirical literature points to the significance of gender in explaining both financial performance and literacy (see, for example, Goldsmith et al., 1997; Hira and Mugenda, 2000; Barber and Odean, 2001; Chen and Volpe, 2002; Xiao, et al., 2006, 2009; Shim, et al., 2009; Lusardi and Mitchell, 201 1; Atkinskon and Messy, 2012; Vehovec et al., 2015). These findings imply that women, in comparison to men, have a lower level of reported financial knowledge and skills, they are less prone to risk and their financial decision-making process is characterized by lower confidence (Wagland and Taylor, 2009).

In this paper, the financial literacy and financial performance of Croatian citizens are examined with the purpose of empirically testing the financial literacy impact as well as gender differences. The research assesses the compliance of the impact of financial literacy and gender on individual financial performance in previous theoretical and empirical research with the estimated impact in Croatia, using cross section linear regression modeling. The study concentrates on the analysis of financial literacy of both genders and assessment of the relationship between financial literacy and gender on the one side and financial performance on the other.

Understanding gender differences in terms of financial literacy and financial prosperity are important for financial educators and policy makers. The financial literacy policy creators are inclined to strengthen the financial position of individuals, and the recognition the need of financial education curriculum designed specifically for men and women is essential for good policy-making. Through dissemination of the test results, this research is intended to raise the general level of public awareness of the need to conduct more active financial education among women in Croatia.

\section{Literature review}

Financial literacy is a rather "young" topic, and therefore most of the articles investigating its incidence are published in the past decade. Regarding the relationship between financial literacy and various forms of individual financial performance, evidence suggests that highly financially literate individuals demonstrate the more successful financial behavior. Hilgert et al. (2003) suggested that financial literacy might be an important predictor of successful decision making. 
Lusardi (2008) showed that financial literacy influences financial decision-making. Collins (2010) found evidence of positive effect of financial literacy on successful financial behavior.

Regarding Croatia, Barbić (2017) analyzed the impact of financial knowledge and skills on individual financial performance. The mentioned research point to a significant positive correlation of both financial knowledge and financial skills with personal financial performance.

Vehovec (2011) assessed the financial literacy of elderly population in Croatia and concluded that groups of financially literate and illiterate respondents do not differ significantly concerning gender. The possible explanation is that older people did not succeed to acquire knowledge and individual responsibility for planning retirement savings during the transitional period. The possible reason is that the whole form of financing third age relied almost exclusively on public sources of pension insurance until recently.

However, in the later comprehensive research on financial literacy in Croatia, Vehovec et al. (2015) pointed out that female exhibit lower level of financial literacy when compared to male respondents. Many other authors came to the same conclusion in other countries (Boyce and Danes, 1998; Staten et al. 2003; Ameriks et al., 2003; Bernheim and Garrett, 2003; Lusardi, 2004; Lusardi and Mitchell, 2007; Banks and Oldfield, 2007; Bell et al., 2008, 2009; Grinblatt and Keloharju, 2009; Stango and Zinman, 2009; Hung et al., 2009; Lusardi and Tufano, 2009; Banks et al., 2010; Christelis et al., 2010; Gerardi et al., 2010; Smith et al., 2010; Gale and Levine, 2010; van Rooij et al., 2011; van Rooij et al., 2012; Cvrlje et al., 2015) and confirmed the existence of positive relationship between financial literacy and various forms of improved personal finance management practices (for ex. planning for retirement, saving, accumulating wealth etc.).

However, results of financial literacy results, as well as its effectiveness in terms of the financial behavior of individuals, differ substantially among genders. When compared with men, women on average live longer, work shorter and have lower income and lower pensions which make them more vulnerable to the risk of financial problems (Weir and Willis, 2000). The relevant empirical literature points to the lower level of financial literacy of women in relation to men. However, empirical research on that matter is rather scarce. Leach et al. (1999) indicated that research of the effect of gender on financial performance is limited (Falahati and Paim, 2011). Bajtelsmit and Bernasek (1996) point to the conclusion that women and man have different capacity and tendency to use available financial information. Goldsmith and Goldsmith (1997) indicated that men are more self-confident and have higher knowledge regarding financial investment in relation to women (Falahati and Paim, 2011). Hira and Mugenda (2000) pointed to the significant influence of gender on financial perception, behavior, and satisfaction. Their findings suggested that women feel they know less on financial topics such as money management, financial analysis, and investments. Chen and Volpe (2002) presented a similar conclusion, confirming the lower level of financial knowledge of women. Looking at the pattern of responses across gender, Lusardi and Mitchell (2007) concluded that women commonly exhibit lower financial knowledge than men do, and the probability of correct answer in financial literacy questionnaire is lower for women than for men. Moreover, the probability that women will not know the answer is shown to be higher than the probability of answering incorrectly. They confirmed their results in later studies where they found that lower level of knowledge is more often present at women and minority communities (Lusardi and Mitchell, 2007; 2011). Similarly, Zisimopoulos et al. (2008) found that $20 \%$ of middle-aged highly educated 
women accurately answered the basic questions related to simple interest, while at the same question correctly answered $35 \%$ of highly educated men of the same age. According to Alessie et al. (2011), women reported a lower level of financial literacy, and the gender differences were found to be statistically significant. Van Rooij et al. (2011) in their research confirmed the existence of differences in the level of financial literacy with respect to sociodemographic variables, where women showed a lower level of financial literacy than men. Mahdavi and Horton (2014) concluded that the financial literacy even among highly educated and talented women was at the very low level when compared to men. They implied that even highly-educated women were not at the high level of financial literacy. Results of Vehovec et al. (2015) confirmed the assumption of a higher level of financial literacy of men when compared to women. Furthermore, several studies showed that women are less secure in their financial capabilities (Niederle and Vesterlund, 2007; Niederle and Yestrumkas, 2008), which results in different financial outcomes for both genders. Results of the research conducted by Cheng et al. (2011) suggested that there are significant differences in preferences for the use of loans in relation to gender and that woman on average pay higher costs of credit use than men. Several studies went one step further and even explored the reasons that might cause the gender segregation. Hsu (2011) confirmed that the aforementioned differences in financial literacy are caused by different specialization within the household which resulted in the late adoption of financial knowledge and skills by women. Fonseca et al. (2012) and Bucher-Koenen et al. (2012) concluded that the cause of low financial literacy of women could be the low confidence regarding financial decision making. Fonseca et al. (2012) study confirmed Cheng et al. (2011) findings. They concluded that most of the gender differences are determined by the "creation" of financial literacy. One explanation is the division of household chores, where men are dominant in financial activities, while women engage more in other activities within the household.

World Bank (2010a, 2010b) pointed out that effective campaigns are necessary to promote awareness or consumer literacy with a view to better understanding of banking products and services and avoidance of individual financial problems. On the basis of the National Strategic Consumer Financial Literacy Framework for the period 2015-2020 (Official Gazzete, 2015), the Action Plan for Improving Consumer Financial Literacy for 2015 (Official Gazzete, 2015) was adopted by the Government of the Republic of Croatia in 2015.

The Action Plan contains an overview of identified measures and activities in raising the level of consumer literacy, and the Ministry of Finance is responsible for the coordination process and preparation of the Action Plan's implementation.

The measures are defined by the stakeholders in the implementation of financial education as defined by the National Strategic Consumer Financial Literacy Framework. The public institutions and other institutions designated by the individual measures of the Action Plan have the responsibility to carry out the measures and activities within their respective competencies (Croatian Chamber of Commerce, 2017).

Croatian National Bank also has a great role in the process of promoting financial literacy in Croatia. Croatian National Bank (2016) conducted the financial literacy survey in cooperation with the Croatian financial services supervisory agency (Hanfa) and Ministry of Finance. The representative sample comprised over 1000 respondents.

The conducted survey research indicated that individuals with both lower income and education level show lower financial knowledge. They administer manage 
household budgets less often, have inadequate pension planning and are not very familiar with the use of financial products.

\section{Methodology}

The data used in this study is obtained from a survey conducted by Cvrlje (2014). The data consists of 640 randomly chosen respondents living in Croatia, aged 20-79 who are interviewed using telephone survey. Based on data from the survey it is systematically chosen a random sample of 120 respondents (equal number of male and female respondents) living in Croatia, 25-50 years old. Measurement scales used in this study (financial literacy and financial performance) are also adopted from Cvrlje (2014) and the author reported adequate reliability (above 0.8) and convergent validity of the measurement scales (factor loadings 0.6 and above). Financial literacy measure is composed out of seven questions relating to inflation, compound interest, exchange rate, risk awareness, and loans. Financial performance scale is comprised out of 23 items relating to six categories of financial behaviour: (1) consumption management; (2) Securing your future; (3) Informing on personal finances; (4) Attitude and awareness on the necessity of responsible individual finance management; (5) Financial planning; and (6) Financial stability.

In the next step, the linear cross-section regression model with two independent variables is estimated. The dependent variable in the model is financial performance, denoted by $y$. The first explanatory variable is dummy variable gender, denoted by $G$, where $G=0$ for female gender and $G=1$ for the male gender. Financial literacy (denoted by $\mathrm{FL}$ ) is ordinal categorical variable with 4 levels: Completely financially illiterate, financially illiterate, moderately financially literate and highly financially literate. To investigate if financial literacy affects financial performance, the following three dummy variables are chosen for four levels of financial literacy: 1) $\mathrm{FL} 2=1$ if $\mathrm{FL}=$ financially illiterate, $F L 2=0$ else; 2) $F L 3=1$ if $F L=$ Moderate financially literate, $F L 3=0$ else and 3) $F L 4=1$ if $F L=$ High financially literate, $\mathrm{FL} 4=0$ else.

\section{Results}

The multiple regression analysis is conducted using SAS Enterprise Guide 4.3. The cross-section linear regression model is estimated using ordinary least squares method. For an explanation of the model see, for example, Kennedy (2008), Maddala and Lahiri (2010), Greene (2012) and Pejić Bach et al. (2009).

Table 1

Parameter Estimates

\begin{tabular}{lcrrrcc}
\hline Variable & $\begin{array}{c}\text { Parameter } \\
\text { estimate }\end{array}$ & $\begin{array}{c}\text { Standard } \\
\text { error }\end{array}$ & t-statistic & p-value & Tolerance & $\begin{array}{c}\text { Variance } \\
\text { inflation }\end{array}$ \\
\hline Intercept & 64.685 & 2.904 & 22.27 & 0.0000 & - & - \\
G & 5.287 & 2.300 & 2.30 & 0.0234 & 0.956 & 1.046 \\
FL2 & 7.237 & 3.279 & 2.21 & 0.0293 & 0.490 & 2.040 \\
FL3 & 7.568 & 3.558 & 2.13 & 0.0355 & 0.522 & 1.917 \\
FL4 & 10.266 & 3.898 & 2.63 & 0.0096 & 0.577 & 1.734 \\
\hline
\end{tabular}

Source: Authors' calculation 
Table 1 shows regression model parameter estimates, as well as corresponding standard errors, t-statistics, and p-levels, tolerance and variance inflation. The estimated regression model with t-statistics in parentheses is:

$$
\begin{aligned}
& \hat{\mathrm{y}}_{\mathrm{i}}=64.685+5.287 \cdot G_{i}+7.237 \cdot \mathrm{FL} 2_{\mathrm{i}}+7.568 \cdot \mathrm{FL} 3_{\mathrm{i}}+10.267 \cdot \mathrm{FL}_{\mathrm{i}} \\
& \text { (2.904) (2.300) (3.279) (3.558) (3.898) }
\end{aligned}
$$

Since empirical significance levels are less than 0.05 , it can be concluded that all independent variables are significant at $5 \%$ significance. The intercept of equation (1) is 64.68539 and it means the average value of financial performance for the group of women $(G=0)$ at the reference category (Completely financially illiterate) of variable $\mathrm{FL}$. The first regression coefficient $\hat{\beta}_{1}=5.287$ measures the difference in the two intercept terms for man ( $G=1$ ) and women $(G=0)$. The average value of financial performance for man $(G=1)$ at the reference level of variable $F L$ is 69.972 points, or it is 5.287 points higher than the average value of financial performance for women at the same FL level.

Parameters $\hat{\beta}_{2}, \hat{\beta}_{3}, \hat{\beta}_{4}$ in the equation (1) have positive values, and they indicate an average increase in the average value of financial performance for persons who have reached the second, third, or fourth level of FL with respect to persons who are financially completely illiterate. For example, the second regression coefficient $\hat{\beta}_{2}=7.23689$ means that financially illiterate person is on average 7.23689 points financially more successful than the completely financially illiterate persons.

The analysis of variance for the estimated cross-section linear regression model is shown in Table 2.

Table 2

The analysis of variance

\begin{tabular}{lrrrrr}
\hline $\begin{array}{r}\text { Variation } \\
\text { source }\end{array}$ & $\begin{array}{r}\text { Degrees of } \\
\text { freedom }\end{array}$ & $\begin{array}{r}\text { Sum of } \\
\text { Squares }\end{array}$ & $\begin{array}{r}\text { Mean } \\
\text { Square }\end{array}$ & F-statistic & p-value \\
\hline Model & 4 & 2314.04 & 578.51 & 3.81 & 0.0060 \\
Error & 115 & 17453 & 151.76 & & \\
Corrected & 119 & 19767 & & & \\
Total & & & & & \\
\hline
\end{tabular}

Source: Authors' calculation

The F-statistic from Table 2 equals 3.81, with a corresponding empirical significance level of 0.006 . Therefore, the overall regression significance test shows that the regression model is significant at $1 \%$ significance.

Moreover, the summary of the model fit is assessed. The standard error of the estimate is equal to 12.319 points. The associated relative measure is the coefficient of variation, which is equal to $16.65 \%$ and points to the satisfactory representativeness of the estimated regression model. The coefficient of determination equals to 0.1171, what is not unusual in regression models with categorical explanatory variables.

In the next step, the regression model diagnostics are examined. In this paper, White's LM test is conducted in order to test for heteroskedasticity. The LM test statistics equals 4.120614 , with the p-value of 0.7658 . Therefore, at $5 \%$ significance, heteroscedasticity is not present. Moreover, the normality of the model residuals is 
tested using Jarque-Bera test. Figurl shows the Jarque-Bera test statistic, which is equal to 2.5537 and its $p$-value equals 0.2789 , what points to residual normality. Furthermore, the histogram of the residuals is shown in Figure 1.

Figure 1

The descriptive statistics and histogram of the residuals and Jarque-Bera test statistics

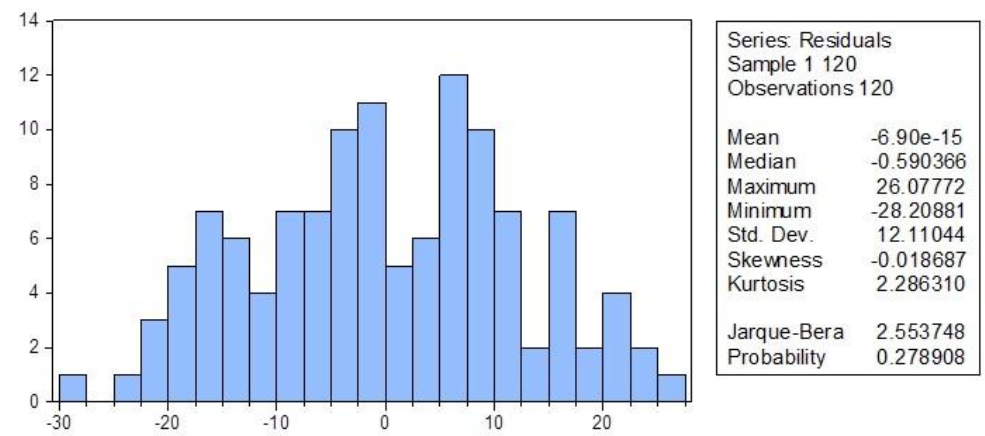

Source: Authors' work (E Views 8)

The existence of multicollinearity is assessed using Variance Inflation Factors (VIF), which are shown in Table 1. Since VIF is less than 5 for all four explanatory variables, the can be concluded that there is no multicollinearity problem in the estimated regression model.

The robustness of obtained estimations to the addition of new explanatory variable is examined estimation of the multiple regression model using age as additional independent variable. The result of the estimation is provided in equation (2). The model diagnostics is also conducted and there is no violation of regression model assumptions. Although age is not significant in explaining financial performance, the signs of other explanatory variables in estimated regression equation remain the same, what points to the fact that previously estimated model robust to the addition of variable age.

$$
\begin{aligned}
\hat{\mathrm{y}}_{\mathrm{i}}= & 71.571-0.21 \cdot A G E_{i}+5.896 \cdot \mathrm{G}_{\mathrm{i}}+6.862 \cdot \mathrm{FL} 2_{\mathrm{i}}+6.929 \cdot \mathrm{FL} 3_{\mathrm{i}}+9.604 \mathrm{FL} 4_{\mathrm{i}} \\
& (7.493)(0.211)
\end{aligned}
$$

\section{Discussion}

This research investigates the relationship among financial literacy, gender and financial performance in the sample of 120 Croatians. The conducted research has shown that financial literacy and gender are both statistically significant in explaining individual financial performance. The findings of this research confirm results of the previous studies regarding the positive impact of financial literacy on individual financial performance and lower level of financial performance of women when compared to men at the same level of financial literacy. As expected, results of the analysis indicate that financial performance increases for each level of improved financial literacy. Similar results were also found in Hilgert et al. (2003), Lusardi, 2004; 2005; 2011; Lusardi and Tufano, 2009; Gerardi et al., 2010; van Rooij et al., 2012, etc. Furthermore, examining gender differences, we find that on average women perform worse than men in the context of personal finance. The average value of financial performance for man is 5.287 points higher than the average value of financial performance for women at the same financial literacy level. These results are in line with the previous research on this subject (Goldsmith and Goldsmith, 1997; 
Chen and Volpe, 2002; Lusardi and Mitchell, 2007; Zisimopoulos et al., 2008; Lusardi and Mitchell, 2011; Falahati and Paim, 2011, etc.) and confirm the existence of gender segregation in terms of financial performance in Croatia.

The results emphasize the significance of financial literacy for individual financial performance and raise concerns on women's ability to reach financial security. As poor financial management problem is found among women, it is necessary for the educators and policy makers to engage in providing an adequate financial education program that should target explicitly women. This may be better suited to address their inclinations, wants, needs, financial knowledge, and skills and the way women acquire and use financial literacy. Moreover, educators should take effective measures in refining and improve people's financial knowledge and skills in order to ensure their enhanced financial performance. The obtained results can be explained by different specialization within the household which resulted in the late adoption of financial knowledge and skills by women, what is outlined in Hsu (2011) as the possible reason of the worse financial performance of women. Moreover, as mentioned earlier, Fonseca et al. (2012), Bucher-Koenen et al. (2012) indicate that women exhibit a low level of self-confidence regarding financial decision making. Also, Cheng et al. (2011) pointed out that most of the gender differences are determined by the different "creation" of financial literacy, whereas men are governing mostly financial activities, while women engage more in other activities within the household.

\section{Conclusion}

This research assessed the importance of financial literacy and gender in achieving financial performance. The results imply that both financial literacy and gender are important variables forming and affecting the financial performance of individuals and thus should be attended with special attention. The results obtained in this research may be a good reference for future research related to personal financial behavior and individual performance in managing personal finances. However, additional research is needed to further advance the current understanding of this area. A challenge for future studies is to examine other variables both those given by birth (as gender) and acquired through life (as financial literacy) that might influence overall individual financial performance. Also, it is necessary to conduct additional research to comprehend why the differences in financial performance among women and men exist and which factors contribute to mentioned differences. The main limitations of this study concern self-reported data which includes the risk of some individuals giving false or desirable answers. However, this concern is present in every research based on survey. Further limitations concern the sample size and the fact it included people aged 25-50 years. Therefore it is advisable to repeat the investigation on a larger sample to make sure the findings are applicable to other age groups as well.

\section{References}

1. Alessie, R., Rooij, M., Lusardi, A. (2011), „Financial Literacy, Retirement Preparation and Pension Expectations in the Netherlands",NBER Working Paper No. 17109.

2. Ameriks, J., Caplin, A., Leahy, J. (2003), "Wealth accumulation and the propensity to plan", Quarterly Journal of Economics, Vol. 118, No. 3, pp. 10071047.

3. Atkinson, A., Messy F. A. (2012), „Measuring Financial Literacy: Results of the OECD/International Network on Financial Education (INFE) Pilot Study", OECD 
Working Papers on Finance, Insurance and Private Pensions, OECD Publishing, No. 15, pp. 1-72.

4. Bahovec, V., Cvrlje, D., Palić, I. (2015), "Testing the effects of financial literacy on debt behavior of financial consumers using multivariate analysis methods", Croatian Operational Research Review, Vol. 6, No. 2, pp. 361-371.

5. Bajtelsmit, V. L., Bernasek, A. (1996), "Why do women invest differently than men?", Journal of Financial Counselling and Planning, Vol. 7, pp. 1-10.

6. Banks, J., O'Dea, C., Oldfield, Z. (2010), "Cognitive function, numeracy and retirement saving trajectories", Economic Journal, Vol. 120, No. 548, pp. 381-410.

7. Banks, J., Oldfield, Z. (2007), „Understanding Pensions: Cognitive Function, Numerical Ability and Retirement Saving", Fiscal studies, Vol. 28, No. 2, pp. 143170.

8. Barber, B. M., Odean, T. (2001), „Boys Will be Boys: Gender, Overconfidence, and Common Stock Investment", Quarterly Journal of Economics, Vol. 116, No. 1, pp. 261-292.

9. Barbić, D. (2017), "Investigating the role of financial knowledge, financial skills and behavioral control in explaining individuals' performance in managing personal finances: The case of Croatia", in Ogutveren, U., Frydkova, E., Pomazan, V. M. (eds), 3rd International Conference on Humanities, Social Sciences and Education, Dubai, pp. 244-249.

10. Bell, C., Gorin, D., Hogarth, J. M. (2008), „Financial education - Does it work and how do we know? Research findings from a study of financial education among soldiers", Community Investments, Vol. 21, No. 2, pp. 15-16.

11. Bell, C., Gorin, D., Hogarth, J. M. (2009), "Does financial education affect soldiers' financial behavior?", Networks Financial Institute Working Paper 2009-WP-08, pp. $1-50$.

12. Bernheim, B. D., Garrett, D. M. (2003), "The effects of financial education in the workplace: Evidence from survey of households", Journal of Public Economics, Vol. 87, No. 7-8, pp. 1487-1519.

13. Boyce L. B., Danes, S. M. (1998), "Evaluation of the NEFE high school financial planning program", National Endowment for Financial Education.

14. Bucher-Koenen, T., Lusardi, A., Alessie, R., van Rooij,M. (2012), "How financially literate are women? Some new perspectives on the gender gap", available at: http://arno.uvt.nl/show.cgiefid=126935 (21 September 2017).

15. Chen, H., Volpe, R. P. (2002), "Gender differences in personal financial literacy among college students", Financial Services Review, Vol. 11, pp. 289-307.

16. Cheng, P., Lin, Z., Liu, Y. (2011), "Do Woman Pay More for Mortgages?", Journal of Real Estate Finance and Economics, Vol. 43, No. 4, pp. 423-440.

17. Christelis, D., Jappelli, T., Padula, M. (2010), „Cognitive abilities and portfolio choice", European Economic Review, Vol. 54, No. 1, pp. 18-38.

18. Collins, J. M. (2010), "The impacts of manadatory financial education: evidence from a randomized field study", Working Paper, Center for financial security, pp. $1-13$

19. Croatian Chamber of Commerce (2017), "Pilot-projekt Financijske pismenosti 2017", available at: http://www.hgk.hr/pilot-projekt-financijske-pismenosti-20172018 (21 September 2017).

20. Croatian National bank (2016), "Results of the financial literacy survey in the Republic of Croatia", available at: https://www.hnb.hr/en/-/predstavljenirezultati-istrazivanja-mjerenje-financijske-pismenosti- (21 September 2017). 
21. Cvrlje, D. (2014), "Povezanost koncepta financijske pismenosti s uspješnošću u upravljanju osobnim financijama", Doctoral thesis, University of Zagreb, Faculty of Economics and Business.

22. Cvrlje, D., Bahovec, V., Palić, I. (2015), "Exploring the Effects of Financial Education: Analysis of Saving Behavior of Croatian Consumers", in Jovancai Stakic, A., Kovsca, V., Bendekovic, J. (eds), Book of Proceedings of the Economic and Social Development (ESD), 5th Eastern European Economic and Social Development Conference on Social Responsibility, Belgrade, Serbia, pp. 241-250.

23. Falahati, L., Paim, L. H. (2011), "Gender differences in financial well-being among college students", Australian Journal of Basic and Applied Sciences, Vol. 5, No. 9, pp. 1765-1776.

24. Fonseca, R., Mullen, K. J., Zamarro, G., Zissimopoulos, J. (2012), "What Explains the Gender Gap in Financial Literacy?", The Journal of Consumer Affairs, Vol. 46, No. 1, pp. 90-106.

25. Gale, W., Levine, R. (2010), "Financial literacy: What works? How could it be effective?", available at: https://www.brookings.edu/wpcontent/uploads/2016/06/10 financial literacy gale levine.pdf (21 September 2017).

26. Gerardi, K., Goette, L., Meier, S. (2010), "Financial literacy and subprime mortgage delinquency: evidence from a survey matched to administrative data", Federal Reserve Bank of Atlanta Working Paper Series, No. 2010-10, pp. 154.

27. Goldsmith, R. E., Goldsmith, E. B. (1997), "Gender differences in perceived and real knowledge of financial investments", Journal of Psychological Reports, Vol. 80, No. 1, pp. 236-238.

28. Goldsmith, R., Goldsmith, E., Heaney, J. (1997), "Sex Differences in Financial Knowledge: A replication and Extension", Psychological Reports, Vol. 81, No. 3, pp. $1169-1170$.

29. Greene, W. H. (2012). Econometric analysis, Upper Saddle River, Pearson Prentice Hall.

30. Grinblatt, M., Keloharju, M. (2009), „Sensation Seeking, Overconfidence, and Trading Activity", Journal of Finance, Vol. 64, No. 2, pp. 549-578.

31. Hilgert, M. A., Hohart, J. M., Beverly, S. G. (2003), "Household Financial Management: The connection between knowledge and behavior", Federal Reserve Bulletin, Vol. 2003, No. 7, pp. 309-322.

32. Hira, K. T., Mugenda, O. (2000), "Do men and women differ in their financial beliefs and behaviors?", Proceedings of the Eastern Family Economics Resource Management Association.

33. Hsu, J. W. (2011), "Aging and Strategic Learning: The Impact of Spousal Incentives on Financial Literacy", Indiana State University Networks Financial Institute Working Paper, 2011 -WP-06.

34. Hung, A. A., Parker, A. M., Yoong, J. K. (2009), "Defining and measuring financial literacy", RAND Working Paper Series WR-708, pp. 1-28.

35. Kennedy, P. (2008). A guide to Econometrics, New Jersey, Wiley Blackwell.

36. Lusardi, A. (2004), "Savings and effectiveness of financial education", Pension Research Council, WP2003-14, pp. 1-45.

37. Lusardi, A. (2005), „Financial Education and the Saving Behavior of AfricanAmerican and Hispanic Households", available at: http://www.dartmouth.edu/ alusardi/Papers/Education African\&Hispanic.pdf (21 September 2017). 
38. Lusardi, A. (2008), "Financial Literacy: Essential Tool for Informed Consumer Choice?", Bulletin on Aging and Health, No. 14084, pp. 1-30.

39. Lusardi, A., Mitchell, O. S. (2007), „Financial Literacy and Retirement Planning: New Evidence from the Random American Life Panel", available at: http://www.dartmouth.edu/ alusardi/Papers/American Life Panel.pdf September 2017).

40. Lusardi, A., Mitchell, O. S. (2011). Implications for retirement security and the financial marketplace, Oxford University Press.

41. Lusardi, A., Tufano, P. (2009), „Debt literacy, financial experiences, and overindebtedness", NBER Working Paper Series, Working Paper 14808.

42. Maddala, G. S., Lahiri, K. (2010). Introduction to Econometrics, New Jersey, Wiley Blackwell.

43. Mahdavi, M., Horton, N. J. (2014), "Financial Knowledge among Educated Women: Room for Improvement", The Journal of Consumer Affairs, Vol. 48, No. 2 , pp. 403-417.

44. Niederle, M., Yestrumskas, A. (2008), "Gender differences in seeking challanges: The role of institutions", NBER Working Paper No. 13922.

45. Niederle, M.,Vesterlund, L. (2007), „Do woman shy away from competition? Do men compete too much?", Quarterly Journal of Economics, Vol. 122, No. 3, pp. 1067-1101.

46. Official Gazzete (2015), National Strategic Consumer Financial Literacy Framework for the period 2015-2020, available at: http://narodnenovine.nn.hr/clanci/sluzbeni/2015 01 11_224.html (10 April 2017).

47. Pejić Bach, M., Posedel, P., Stojanović A. (2009), "Determinante profitabilnosti banaka u Hrvatskoj", Zbornik ekonomskog fakulteta u Zagrebu, Vol. 7, No. 1, pp. 81-92.

48. Shim, S., Xiao, J. J., Barber, B. L., Lyons, A. (2009), "Financial socialization of firstyear college students: The roles of parents, work, and education", Journal of Youth Adolescence, Vol. 39, No. 12, pp. 1457-1470.

49. Smith, J., McArdle, J., Willis, R. (2010), „Financial decision making and cognition in a family context", Economic Journal, Vol. 120, No. 548, pp. 363-380.

50. Stango, V., Zinman, J. (2009), "Exponential Growth Bias and Household Finance", Journal of Finance, Vol. 64, No. 6, pp. 2807- 2849.

51. Staten, M. S., Elliehausen, G., Lundquist, E. C. (2003), "The impact of credit counseling on subsequent borrower credit usage and payment behavior", Credit Research Center, pp. 1-36.

52. Van Rooij, M. C. J., Lusardi, A., Alessie, R. J. M. (2011), „Financial literacy and retirement planning in the Netherlands", Journal of Economic Psychology, Vol. 32, No. 4, pp. 593-608.

53. Van Rooij, M. C. J., Lusardi, A., Alessie, R. J. M. (2012), „Financial literacy, retirement planning and household wealth", The Economic Journal, Vol. 112, No. 560, pp. 449-478.

54. Vehovec, M. (2011), "Financijska i mirovinska pismenost: međunarodna iskustva i prijedlozi za Hrvatsku", Privredna kretanja i ekonomska politika, Vol. 21, No. 129, pp. 65-85.

55. Vehovec, M., Rajh, E., Škreblin Kirbiš, I. (2015), "Financijska pismenost građana U Hrvatskoj", Privredna kretanja i ekonomska politika, Vol. 24. No. 1, pp. 53-75.

56. Wagland, S. P., Taylor, S. S. (2009), "When it comes to financial literacy, is gender really an issue?", Australasian Accounting Business and Finance Journal, Vol. 3, No. 1, pp. 13-25. 
57. Weir, D. R., Willis, R. J. (2000), „Prospects for Widow Poverty in the Finances of Married Couples in the HRS", in Mitchell, O. S., Hammond, P. B., Rappaport, A. M. (eds), Forecasting Retirement Needs and Retirement Wealth, University of Pennsylvania Pres, pp. 208-234.

58. World Bank (2010a). Hrvatska - Dijagnostički pregled zaštite potrošača i financijske pismenosti, Svezak I: Glavni nalazi i preporuke, veljača, Zagreb, World Bank.

59. World Bank (2010b). Hrvatska - Dijagnostički pregled zaštite potrošača i financijske pismenosti", Svezak II: Usporedba s dobrim praksama, Zagreb, World Bank.

60. Xiao, J. J., Sorhaindo, B., Garman, E. T. (2006), „Financial behavior of consumers in credit counseling", International Journal of Consumer Studies, Vol. 30, No. 2 , pp. 108-121.

61. Xiao, J. J., Tang, C., Shim, S. (2009), "Acting for Hapiness: Financial Behavior and Life Satisfaction of College Students", Social Indicator Research, Vol. 92, No. 1, pp. 53-68.

62. Zissimopolus, J., Karney, B., Raver, A. (2008), "Marital histories and economic wellbeing", MRRC Working Paper, WP2008-645, pp. 1-30. 


\section{About the authors}

Vlasta Bahovec graduated from the Faculty of Science in Zagreb in 1972, majoring in practical mathematics. In the same year, she was elected at the Faculty of Economics and Business, the University of Zagreb as an assistant in statistical disciplines. She gained her MSc degree in 1979, and Ph.D. in economics at the Faculty of Economics and Business, the University of Zagreb in 1987. In 1990 she became an assistant professor, in 2003 full professor and in 2010 full professor tenure at Department of statistics. Her scientific and professional papers are from the field of regression analysis and analysis of time series. In academic year 1996/97, she held the position of the head of the Department of Statistics at the Faculty of Economics and Business, the University of Zagreb From 2006 to 2009 she was the Vice-Dean for Teaching and Students at the Faculty of Economics and Business, University of Zagreb. She has been retired since 2015. She actively publishes scientific papers after retirement. She can be contacted at vbahovec@efzg.hr.

Dajana Barbic graduated in 2008 at the Faculty of Economics and Business, University of Zagreb, majoring in Finance. During the study, she has been awarded Dean's Award four times for great success during her study and Rector's Award. Also, she received The City of Zagreb scholarship. She post-graduate in Managing Financial Institutions and gained a Ph.D. degree in Business Economics at Faculty of Economics and Business, University of Zagreb. She is currently employed as Assistant Professor at the Department of Finance, Faculty of Economics and Business, University of Zagreb. From 2008 she teaches following courses: Personal finance, Public finance, Monetary policy and Tax Systems in Croatia. Her main research fields include financial literacy and personal finances, public finance, tax literacy and taxation, and income inequality. She has published many scientific papers and participated in international scientific conferences. As part of the Erasmus program for professional training in March 2014 she stayed at Wirtschaftsuniversitat in Vienna and in 2013 she visited Universita del Salento in Lecce, Italy. She is dedicated to the financial education of citizens, especially young, and she is a member and cofounder of the Institute for financial education - Štedopis. She can be contacted at dbarbic@efzg.hr.

Irena Palić graduated in 2008 at the Faculty of Economics and Business, University of Zagreb, majoring in Finance. During the study, she has been awarded Dean's Award four times for great success and results achieved. Also, she received The City of Zagreb scholarship and the State Scholarship of the Ministry of Science, Education, and Sports. She post-graduate in Statistical Methods for Economic Analysis and Forecasting and gained a Ph.D. degree in Economics at Faculty of Economics and Business, University of Zagreb. She is currently employed as Assistant Professor at the Department of Statistics, Faculty of Economics and Business, University of Zagreb. From 2008 she teaches following courses: Statistics, Sampling methods, Business Statistics, Statistical methods in professional and scientific work, Statistical methods of research in tourism. Her main research fields are the application of statistics and econometrics in business, finance and economics, multivariate methods and dynamic stochastic general equilibrium models. She has published 29 scientific papers and participated in 17 scientific conferences. As part of the Erasmus program for professional training in March 2014, she stayed at Wirtschaftsuniversitat in Vienna. She can be contacted at ipalic@efzg.hr. 